\title{
Normative regulation of material incentives for workers in the sphere of high-rise construction
}

\author{
Anna Kopytova ${ }^{1 *}$, Elena Matys ${ }^{1}$, Natalia Zotkina ${ }^{1}$, Irina Reshetnikova $^{1}$, Natalia Meller ${ }^{1}$, \\ Inna Nekrasova $^{1}$ \\ ${ }^{1}$ Tyumen Industrial University, Volodarskogo str., 38, Tyumen, 625000, Russia
}

\begin{abstract}
The article is devoted to the problem of normative and legal regulation of incentives for workers of the building companies. The company considered is engaged in high-rise construction. The part of the document "Regulations for the incentives of employees of the enterprise" is presented. This document is introduced into the practical activities of the Tyumen enterprise. The presented part of the document regulates the issues of material incentives for employees of the enterprise. The document "Regulations for the incentives of employees of the enterprise" is developed in accordance with the approach proposed by author. The document was developed, after the authors had carried out an analysis of the scheme of incentives at the enterprise.
\end{abstract}

\section{Introduction}

In a highly competitive environment, trade organizations need to look for reserves to improve the efficiency of their activities. Successful work in the service sector assumes that the staff of the enterprise has certain incentives, which, in turn, is impossible without an appropriate effective incentive system.

Material incentives for workers in a construction enterprise are the most important motivational unit that affects the effectiveness of the organization. [1- 10]

\section{Methodology}

When creating a system of incentives for workers in a construction organization, a rational incentive system was used (Fig. 1). [4, 6, 7]

An important feature of a rational incentive system is that it makes possible selfdetermination by the organizations (according to the needs of workers as well as their own capabilities, available resources and the existing limitations) of the structure of their incentive system [8]. The proposed model provides a choice (like the menu in the cafeteria) by the organization needed and possible (rational for it) components of the incentive system.

For the Tyumen construction company, we developed a document "Regulations for the incentives of employees of the enterprise." The article provides an overview of a part of this document, namely, material incentives for employees.

\footnotetext{
*Corresponding author: a.copytowa@yandex.ru
} 


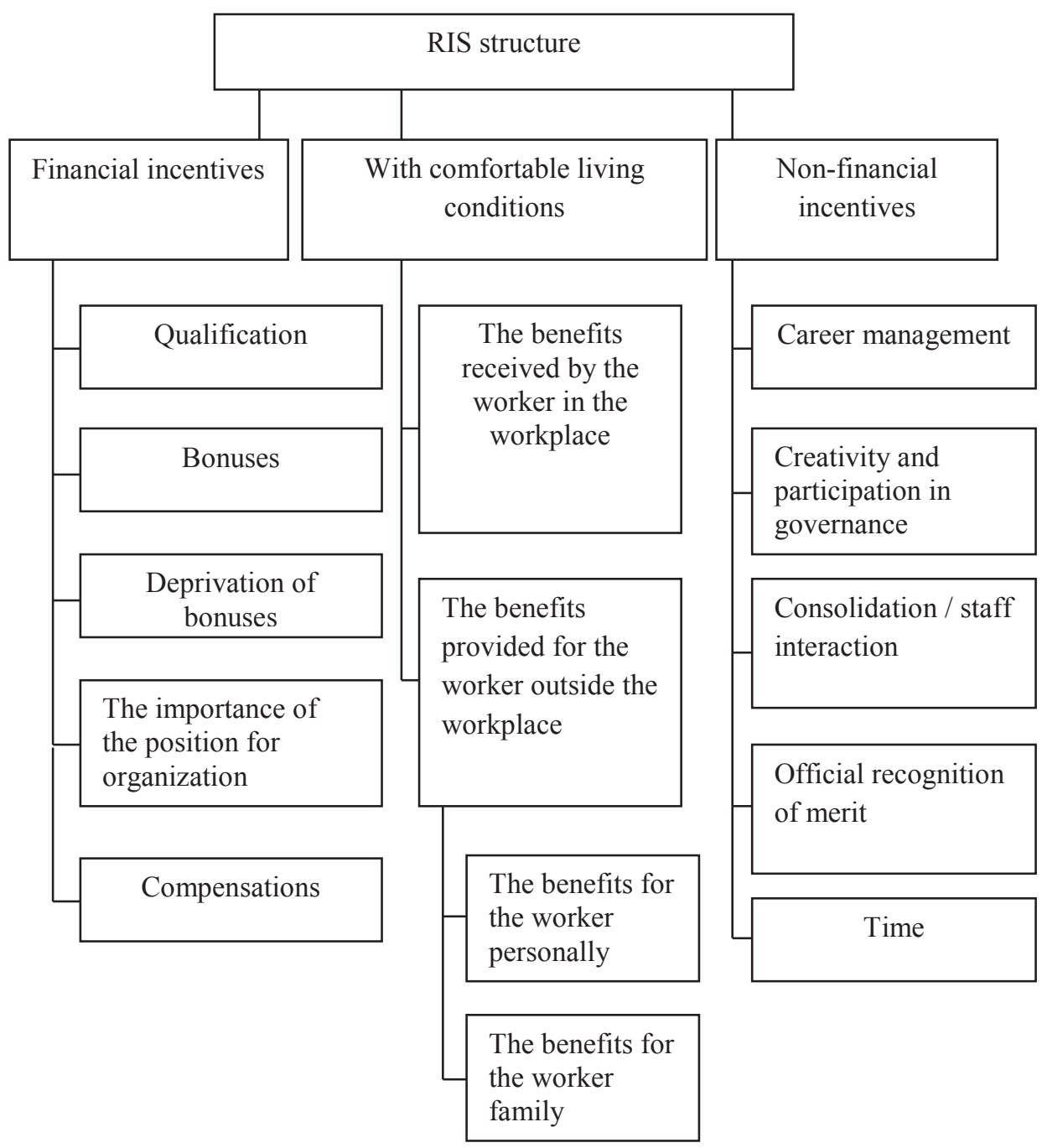

Fig. 1. Model and structure of the rational incentive system.

\section{Results}

Material incentive is one of three types of incentives (material, non-material and stimulating with comfortable living conditions) and includes five components: qualification, bonuses, deprivation of bonuses, importance of the post for organization, compensations. Taking into account these five elements, the material incentive unit, which is part of the "Regulations of incentives for employees of the enterprise," was developed at the enterprise.

The first element is qualificationю. it provides for the assessment of the employee in four areas: the level of education, the compliance of the employee's education with the position held, the length of service in the position held and the length of service in the organization.

1. The level of education. Salary increases in accordance with the assessment scale presented in Table. 1. 
Table 1. Remuneration rate according with the employee's education level

\begin{tabular}{|c|l|c|}
\hline$№$ & \multicolumn{1}{|c|}{ Education } & Coefficient to the salary \\
\hline 1 & General, secondary, primary vocational & - \\
\hline 2 & Secondary vocational & 1,02 \\
\hline 3 & Higher professional education & 1,05 \\
\hline 4 & Few University diplomas & 1,1 \\
\hline
\end{tabular}

Thus, an employee with a secondary vocational education receives a bonus of $2 \%$ of salary monthly, and an employee with a higher education has bonus of $5 \%$ of salary.

2. For the compliance of the education of an employee with the position held by him, an additional payment of $5 \%$ to the salary is provided. The enterprise under consideration is a trade organization with a small number of personnel, most of the employees have the right to receive such a payment.

3. Length of service in the position held. The estimated scale is presented in Table. 2.

Table 2. Coefficients of remuneration for length of service in a particular profession

\begin{tabular}{|c|c|c|}
\hline № & Length of service in the position held & Coefficient to the salary \\
\hline 1 & Up to 3 years & - \\
\hline 2 & From 3 to 5 years & 1,03 \\
\hline 3 & From 5 to 10 years & 1,05 \\
\hline 4 & More than 10 years & 1,1 \\
\hline
\end{tabular}

4. Length of service in the organization. Remuneration of employees is carried out in accordance with Table. 3 .

Table 3. Coefficients of remuneration for length of service in the organization

\begin{tabular}{|c|l|c|}
\hline № & \multicolumn{1}{|c|}{ Length of service in the organization } & Coefficient to the salary \\
\hline 1 & Up to 3 years & - \\
\hline 2 & From 3 to 7 years & 1,07 \\
\hline 3 & More than 7 years & 1,12 \\
\hline
\end{tabular}

The component "Bonuses" includes two elements:

1. Fulfillment of planned targets. Planned targets for the positions of employees are established taking into account the functional duties approved in the job descriptions of the organization and are accepted in accordance with Table. 4.

Table 4. Efficiency indicators for employees' positions

\begin{tabular}{|c|c|c|}
\hline Profession & Indicator & Remuneration \\
\hline \multirow{3}{*}{ Accountant } & Absence of sanctions by tax authorities & $15 \%$ to the salary \\
\hline & $\begin{array}{l}\text { Compliance of work with the established } \\
\text { terms (timely submission of accounts, } \\
\text { calculation of wages, absence of overdue } \\
\text { receivables, etc.) }\end{array}$ & $15 \%$ to the salary \\
\hline & Optimization of taxation & $\begin{array}{l}20 \% \text { of the identified benefits } \\
\text { to the organization }\end{array}$ \\
\hline \multirow{4}{*}{$\begin{array}{l}\text { Sales } \\
\text { Manager }\end{array}$} & Number of new customers & $0,01 \%$ to the salary \\
\hline & $\begin{array}{l}\begin{array}{l}\text { Customer satisfaction } \\
\text { complaints, litigation, etc.) }\end{array} \\
\text { (no claims, }\end{array}$ & $15 \%$ to the salary \\
\hline & Sales level (volume, growth rate) & $\begin{array}{l}2 \% \text { of manager sales; } 5 \% \text { of } \\
\text { sales in excess of the plan }\end{array}$ \\
\hline & Quality of documents (no comments) & $10 \%$ to the salary \\
\hline
\end{tabular}




\begin{tabular}{|c|c|c|}
\hline Profession & Indicator & Remuneration \\
\hline \multirow[t]{2}{*}{$\begin{array}{l}\text { Warehouse } \\
\text { employees }\end{array}$} & $\begin{array}{l}\text { The percentage of losses in the total } \\
\text { volume (one need to strive to reduce the } \\
\text { breackage, damage of goods during the } \\
\text { picking, storage, movement in the } \\
\text { warehouse) }\end{array}$ & $\begin{array}{l}15 \% \text { to salary, if the } \\
\text { established limits are observed }\end{array}$ \\
\hline & $\begin{array}{l}\text { Material flow of the warehouse (workload, } \\
\text { implementation of the plan) }\end{array}$ & $\begin{array}{l}15 \% \text { of the salary when the } \\
\text { plan is implemented }\end{array}$ \\
\hline \multirow{3}{*}{$\begin{array}{l}\text { Commercial } \\
\text { Director }\end{array}$} & $\begin{array}{l}\text { Increase of profits through marketing } \\
\text { activities }\end{array}$ & $\begin{array}{l}20 \% \text { of the profit received } \\
\text { through marketing activities }\end{array}$ \\
\hline & $\begin{array}{l}\text { Introduction of innovations (allocation of } \\
\text { additional spheres of activity - filling the } \\
\text { market, partial change of service, etc.) }\end{array}$ & $\begin{array}{l}20 \% \text { of the benefit of the } \\
\text { enterprise through the } \\
\text { introduction of innovations }\end{array}$ \\
\hline & Revenues from sales & $\begin{array}{l}2 \% \text { of sales, } 4 \% \text { of revenue in } \\
\text { excess of the plan }\end{array}$ \\
\hline \multirow[b]{3}{*}{ Lawyer } & Faultless execution of documents & $20 \%$ to the salary \\
\hline & $\begin{array}{l}\text { The amount of work (the number of vessels } \\
\text { won, the number of inspections, etc.) }\end{array}$ & $\begin{array}{l}15 \% \text { to the salary when the } \\
\text { plan is implemented }\end{array}$ \\
\hline & Knowledge of the legislative framework & $\begin{array}{l}15 \% \text { to salary in the absence of } \\
\text { cases of identification of non- } \\
\text { competence of a lawyer in the } \\
\text { legislative framework of } \\
\text { different areas }\end{array}$ \\
\hline
\end{tabular}

2. Compliance with the working time regime (labor discipline). Payments occur once a quarter. Absence of admissions (considered on the basis of the schedule approved at the beginning of each month) for sickness, schooling and other valid reasons is rewarded with a bonus of $7 \%$ of the official salary.[11, 12, 13, 14]

The component "Deprivation of bonuses" provides for two elements:

1. Violation of the workflow. Personnel actions that entailed material losses (sanctions on the part of counterparties, etc.), changes in the quality of products sold, inappropriate execution of documents, worsening of the opinion of contact groups on the quality of the enterprise, litigation of the enterprise with various subjects, etc. can lead to the deprivation of the employee of the entire stimulating part of the payment. [15, 16, 17, 18]

2. Violation of discipline (the presence of delays, appearance in the workplace in an unacceptable form, etc.) may entail the deprivation of the employee of the entire stimulating part of the payment.

The component "The importance of the post for the organization" implies an additional payment for those professions that are recognized as the most significant for the enterprise. Coefficients of surcharge for the importance of the post for the Tyumen enterprise under consideration are presented in Table 5.

Table 5. Coefficients of additional payments for the importance of individual posts

\begin{tabular}{|c|l|c|}
\hline № & \multicolumn{1}{|c|}{ Post } & Coefficient to the salary \\
\hline 1 & Commercial Director & 1,1 \\
\hline 2 & Accountant & 1,08 \\
\hline 3 & $\begin{array}{l}\text { Sales managers who fulfilled the plan for the } \\
\text { previous 3 months }\end{array}$ & 1,1 \\
\hline
\end{tabular}

Payments for the "Compensation" component are made when recognizing the presence of harmful labor conditions for certain posts in accordance with the current legislation of the Russian Federation:

— if the time for rest is decreased (work at holidays, weekends); 
- if there is the impact on biorhythms of sleep and wakefulness of a person;

- if there are high physical and mental loads, etc.

\section{Discussion}

Material incentives for workers in a construction organization are the powerful tool for influencing the work activity of workers. [11, 19, 20, 21, 22, 23, 24, 25] Material incentives include: wages, bonuses, allowances, surcharges, compensations. This grouping can be considered in a different ways, which may be a direction for further research.

Wages are characterized by remuneration for work, depending on the qualifications of the employee, the complexity, quantity, quality and conditions of the work performed.

Bonuses are used to stimulate the quality of performance and overfulfilment of the plans (tasks) put. Thanks to such an incentive element as bonus, the economic interrelation between the growth of the effectiveness of the organization and the increase in wages is manifested. Bonuses can be of a systematic or one-time nature. The incentive bonuses may not depend on the results of work (paid for the holidays).

Supplements are used to stimulate conscientious attitude to work, increase the efficiency of workers, auxiliary processes.

Stimulating surcharges give impetus to the development of skills. If the employee has sufficient knowledge and skills to perform work of higher qualification than required by the position held, the employer can entrust him with this work with an appropriate surcharge.

Compensation is used at enterprises with harmful working conditions; with a decrease in the time for rest (working at holidays, weekends); in conditions of influence on biorhythms of sleep and wakefulness of the person; in the conditions of high physical and mental loads, etc. Such payments can be used for employees of laboratories, lifters, security guards, etc.

\section{Conclusions}

Thus, the material incentive system developed for the Tyumen Construction Company within the framework of the regulations for the stimulation of employees currently operates and extends to all employees of the organization. And it provides five components: qualification, bonuses, deprivation of bonuses, the importance of the post for the organization, compensation.

\section{References}

1. M. Froli, F. Laccone, Journal of Architectural Engineering 24(1), 04017030 (2018) DOI: 10.1061/(ASCE)AE.1943-5568.0000285

2. J.M. Stritch, R.K. Christensen, International Journal of Manpower 37-5, 840-858 (2016) DOI: 10.1108/IJM-12-2014-0249

3. M. Gravit, O. Zybina, A. Vaititckii, A. Kopytova, Advances in Intelligent Systems and Computing 692, 1093-1101 (2018) DOI: 10.1007/978-3-319-70987-1_118

4. N. Zotkina, M. Gusarova, A. Kopytova, Advances in Intelligent Systems and Computing 692, 1204-1213 (2018) DOI: 10.1007/978-3-319-70987-1_129

5. M. TepePublic Management Review 18-4, 508-538 (2016) DOI: 10.1080/14719037.2015.1014396

6. A. Kopytova, Procedia Engineering $\quad \mathbf{1 6 5}, 1132 \quad$ (2016)
10.1016/j.proeng.2016.11.830 
7. A. Kopytova, MATEC Web of Conferences, 106, 08056 (2017) DOI: 10.1051/matecconf/201710608056

8. N. Zotkina, S. Bardasov, M. Gusarova, A. Kopytova, MATEC Web of Conferences, 106, 08050 (2017) DOI: 10.1051/matecconf/201710608050

9. K. Pykhtin, T. Simankina, V. Sharmanov, A. Kopytova, IOP Conference Series: Earth and Environmental Science, 90 (1), 012065 (2017) DOI: 10.1088/1755$1315 / 90 / 1 / 012065$

10. N.S. Zotkina, Finances and Credit 48 (480), 21-28 (2011)

11. V. Lezier, M. Gusarova, A. Kopytova, IOP Conference Series: Earth and Environmental Science, 90 (1), 012034 (2017) DOI: 10.1088/1755-1315/90/1/012034

12. A. Minnullina, R. Abdrazakov, Advances in Intelligent Systems and Computing 692, 1224-1233 (2018) DOI: 10.1007/978-3-319-70987-1_131

13. A.I. Kazannik, Bulletin of Omsk University 4 (33), 35-43 (2012)

14. A.V. Kopytova, Exchange of intellectual property 3 (XIV), 31-37 (2015)

15. B. Liu, J.L. Perry, Review of Public Personnel Administration 36-1, 4-30 (2016) DOI: $10.1177 / 0734371 X 14549672$

16. A. Minnullina, R. Abdrazakov, IOP Conference Series: Earth and Environmental Science, 90 (1), 012089 (2017) DOI: 10.1088/1755-1315/90/1/012089

17. J. Yeo, International Journal of Public Administration 39-3, 216-225 (2016) DOI: $10.1080 / 01900692.2015 .1004083$

18. M.S. Gusarova, A.V. Kopytova, Bulletin of Omsk University 4,14-22 (2014)

19. N.S. Zotkina, A.V. Kopytova, Economics and entrepreneurship 12-2(53-2),714-719 (2014)

20. V. Lezier, M. Gusarova, A. Kopytova, IOP Conference Series: Earth and Environmental Science, 90 (1), 012069 (2017) DOI: 10.1088/1755-1315/90/1/012069

21. A. Mottaeva, A. Minnullina, IOP Conference Series: Earth and Environmental Science, 90 (1), 012123 (2017) DOI: 10.1088/1755-1315/90/1/012123

22. M. Gravit, O. Zybina, A. Vaititckii, A. Kopytova, IOP Conference Series: Earth and Environmental Science, 90 (1), 012103 (2017) DOI: 10.1088/1755-1315/90/1/012103

23. E.A. Mitrofanova, Personnel and intellectual resources management in Russia 2, 36-41 (2014)

24. N. Zotkina, A. Kopytova, M. Zenkina, O. Zhigunova, MATEC Web of Conferences, 106, 08058 (2017) DOI: 10.1051/matecconf/201710608058

25. A. Minnullina, MATEC Web of Conferences, 106, 08067 (2017) DOI: 10.1051/matecconf/201710608067 